\title{
A Method for Optimizing Technical Parameters of the Vacuum Freeze-Drying Process
}

DOI: 10.15255/KUI.2013.011

KUI-17/2014

Received May 31, 2013

Accepted August 16, 2013

\author{
X.-M. Qian, ${ }^{*}$ W.-R. Huang, and P.-H. Lou \\ College of Mechanical and Electrical Engineering, Nanjing University of Aeronautics and Astronautics, \\ 210016 Nanjing, P. R. China
}

\begin{abstract}
Vacuum freeze-drying is a technique that makes a material dehydrate at low temperature and low pressure, and it has many merits. A control system is designed and developed based on a certain area freeze-drying machine. A test by the control system is done to optimize the freeze-drying technical parameters. According to the test results, by the method of quadratic orthogonal experiment, the key parameters, including duration, temperature and vacuum of freeze-drying, are analysed and optimized. The test proves the optimized parameters valid for certain vacuum freeze-drying machines and certain bacterins. Furthermore, the optimized parameters show that the vacuum freeze-drying method is useful for any area vacuum freeze-drying machine and any bacterin.
\end{abstract}

Key words: Vacuum freeze-drying, control system, technical parameters, optimizing

\section{Introduction}

Vacuum freeze-drying has been considered the best dehydration process for thermolabile products because it reduces nutritional and sensorial degradation. As water is removed from a pre-frozen product, a porous structure is formed, which results in a dehydrated product that has better properties when rehydrated. ${ }^{1}$ This technique springs up rapidly along with the development of refrigeration, vacuum, biology, electronics and therefore it belongs to a multi-subject synthetically utilizing technology. ${ }^{2}$ The vacuum freeze-drying technique is applied to food industry, biology pharmacy industry, medical treatment industry and health care product industry. ${ }^{3}$

The material with vacuum freeze-drying technique may not only keep the intrinsic colour, scent, flavour, shape, but also keep the biochemical characteristics, pharmacological properties by the greatest extent. ${ }^{4,5}$ However, as for most farm products and by-products such as meat, paultry, eggs, aquatic products, vegetables, melon and fruit, the technical parameters have less influence on the quality, while for vaccine, the technical parameters are very important for the quality. ${ }^{6}$ Improper technical parameters will debase the biological activities and immune function.

However, the vacuum freeze-drying technique is a time-consuming and relatively costly, as well as complex process, ${ }^{7}$ especially for the control of technical parameters which are crucial for the quality of the product. All this limits its use to products with high added value. It is important to find a method for the balance of productivity and quality.

\footnotetext{
*Corresponding author: Dr. Xiao-Ming Qian

e-mail: drqian@nuaa.edu.cn
}

In this paper, a vacuum freeze-drying machine was developed jointly by the authors and Nanjing Pharmaceuticals and Instruments Factory. The control system was also programmed to provide a universal method for optimizing vacuum freeze-drying process parameters. A method of quadratic orthogonal with multiple regression models to optimize technical parameters is advanced. The material and the devise both originate from Nanjing Pharmaceuticals and Instruments Factory. Its products include avian influenza vaccine, porcine blue-ear disease vaccine, foot-and-mouth disease vaccine and vacuum freeze-drying machine. The material used in this paper is avian influenza vaccine and the machine used has ten square metres.

\section{Experimental Setup and Vacuum Freeze-Drying Process}

It's important for the vacuum freeze-drying technique to judge the end-point of sublimation. Sublimation is the main dehydrofreezing phase. If the sublimation is inadequate, there will be too much residual ice and the heating will cause eutectic melting which will result in the failure of freeze-drying. On the other hand, if the sublimation is excessive, the heating will raise the temperature of the material instead of sublimation, which will result in disintegration and debasing of the biological activities of the material. In addition, more time consumed for sublimation will reduce the productivity.

It is important to find proper parameters for the whole vacuum freeze-drying process, especially for the sublimation phase. The most important parameters are temperature, vacuum, and sublimation duration. In order to obtain good parameters, the vacuum freeze-drying procedure is analysed and the control system according to the process for the vacuum freeze-drying machine is set up. 


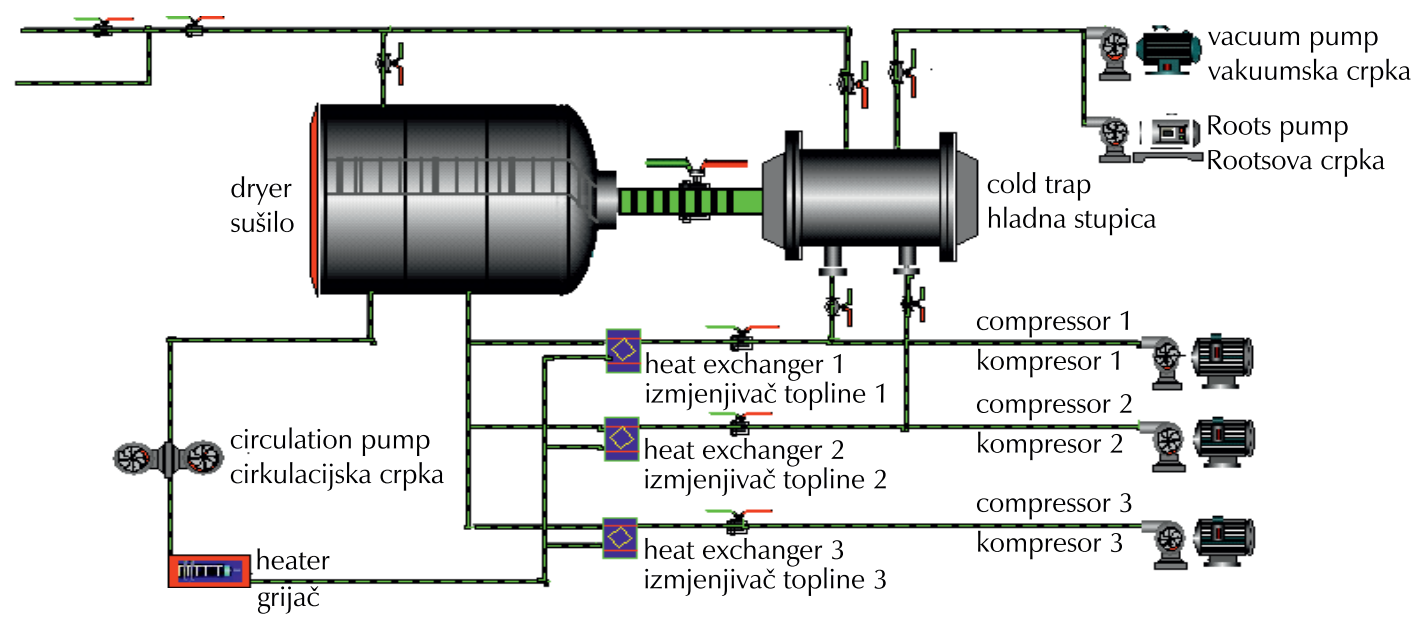

Fig. 1 - Experimental setup of vacuum freeze-drying machine Slika 1 - Eksperimentalni liofilizator

Fig. 1 shows a sketch of the experimental device used to perform the vacuum freeze-drying process. The device includes dryer, cold trap, three compressors, vacuum pump, roots pump, circulation pump, heater, heat exchangers and server valves which are used to do the logical control.

The control system of the machine, as shown in Fig. 2, requires a computer for data storage, calculation and printing, a programmable logic controller (PLC) for logical control, and a data acquisition card (DAQ card) connected with some sensors for temperature and vacuum monitoring in the dryer and cold trap. According to the temperature and vacuum, the control system could judge the end-point of sublimation and measure the residual water content. Then the control system sends the logical commands to the PLC to control all valves and pumps to start or stop in order to obtain optimized technical parameters for the vacuum freeze-drying process. The whole process is as follows:

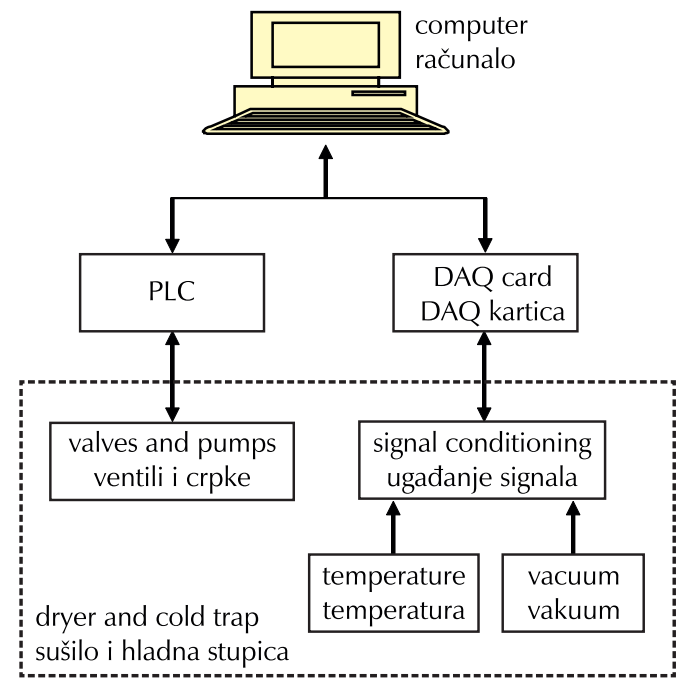

Fi g . 2 - Control system for vacuum freeze-drying machine Slika 2 -Kontrolni sustav liofilizatora a) Add material to dryer and start the control system.

b) Start compressors to refrigerate the dryer. The refrigeration time and temperature could be set up and stored in the computer. When the refrigeration time and temperature both meet the setup value, turn on the valve between the compressors and cold trap in order to refrigerate the cold trap, meanwhile maintain the temperature in the dryer.

C) Start vacuum pump when cold trap temperature equals initialization and turn on two valves in the following order, the one between vacuum pump and cold trap, and the other between cold trap and dryer. Then start roots pump as the vacuum is equal to initialization.

d) Sublimation process. There are some requirements that must be meet in order to begin sublimation, including the temperature and vacuum in the dryer and cold trap, and the duration of maintaining temperature and vacuum. The heater will start when the temperature and vacuum, which could be inspected by sensors, are equal to the initialization. During the process, the heater and compressors will start or stop according to the temperature change, and the valves will be turned on/off to adjust the vacuum.

During the sublimation process, if the temperature and vacuum in the dryer and cold trap are correspondingly constant, the control system could decide the end-point of sublimation as the duration of sublimation is due.

e) Termination of freeze-drying is determined by the content of residual water. The basic principle is to turn off the valve between the dryer and cold trap and inspect the vacuum in the dryer, as

$$
\Delta p / \Delta t \leq V_{c},
$$

where $\Delta t$ is an interval, $\Delta p$ is the dryer pressure change, and $V_{c}$ is a preset value. If the $\Delta p / \Delta t$ does not exceeds $V_{c}$ freeze-drying finishes, otherwise turn on the valve and continue step d) until the requirement of Eq. 1 is met. 


\section{Vacuum Freeze-Drying Process Parameters Optimizing}

During the vacuum freeze-drying process, we should set up some technical parameters in order to improve the productivity and keep biochemical characteristics and pharmacological property of the animal vaccine. From the process mentioned above, there are three important technical parameters for the vacuum freeze-drying process, including temperature and vacuum in dryer and duration of sublimation process to maintain the temperature and vacuum.

Table 1 - Experimental parameters' grades and values Tabli ca 1 - Ocjene $i$ vrijednosti eksperimentalnih podataka

\begin{tabular}{c|c|c|c}
\hline $\begin{array}{c}\text { Grade } \\
\text { Ocjena }\end{array}$ & $\begin{array}{c}\text { Temperature } /{ }^{\circ} \mathrm{C} \\
\text { Temperatura } /{ }^{\circ} \mathrm{C}\end{array}$ & $\begin{array}{c}\text { Vacuum } / \mathrm{Pa} \\
\text { Vakuum } / \mathrm{Pa}\end{array}$ & $\begin{array}{c}\text { Duration } / \mathrm{h} \\
\text { Trajanje } / \mathrm{h}\end{array}$ \\
\hline $\begin{array}{c}\text { high } \\
\text { visoko }\end{array}$ & -50 & 0 & 25 \\
$\begin{array}{c}\text { medium } \\
\text { srednje } \\
\text { low } \\
\text { nisko }\end{array}$ & -60 & 1 & 30 \\
\hline
\end{tabular}

These three key technical parameters are not only decided by the material, but also by the surface area of the freeze-drying machine. In the experiment, the machine is given and the surface area of the machine is constant at ten square meters. Quadratic orthogonal method with three factors is used to optimize the three key technical parameters and to analyse the influence on the material quality.

The grade and value for the experiment parameters are shown in Table 1 . The quality of the material to be frozen and dried will be divided in five ranks, which are excellent (5), good (4), medium (3), passing (2) and poor (1). As far as the quality is concerned, this paper only focuses on the result instead of the inspection process and evaluation standard of the material.

The result of the experiment is shown in Table 2. In the experiment, there are three technical parameters with three grades respectively. By orthogonal table, only nine (rather than 27) experiments were conducted. From the Table 2, as long as the freeze-drying temperature, vacuum and duration of sublimation process are in the permitted range, the quality of the vaccine is always under control. But in order to obtain higher quality, a multiple regression model is set up. All data in Table 2 are saved in Excel and by using the software SPSS for multiple regression model, the regression model for quality with freeze-drying temperature, vacuum and duration is as Eq. 2.

$$
\begin{aligned}
Y= & 16.4521+0.3024 \cdot x_{1}-3.7079 \cdot x_{2}-0.1424 \cdot x_{3}- \\
& -0.0028 \cdot x_{1}{ }^{2}-1.397 \cdot x_{2}{ }^{2}-0.0206 \cdot x_{3}{ }^{2}+ \\
& +0.0209 \cdot x_{1} \cdot x_{2}-0.0212 \cdot x_{1} \cdot x_{3}+0.248 \cdot x_{2} \cdot x_{3},
\end{aligned}
$$

where $x_{1}$ is for freeze-drying temperature, $x_{2}$ is for vacuum and $x_{3}$ is for duration of freeze-drying. Their value ranges are:

\begin{tabular}{|c|c|c|c|c|}
\hline ID & $\begin{array}{l}\text { Temperature } /{ }^{\circ} \mathrm{C} \\
\text { Temperatura } /{ }^{\circ} \mathrm{C}\end{array}$ & $\begin{array}{c}\text { Pressure / Pa } \\
\text { Tlak/Pa }\end{array}$ & $\begin{array}{c}\text { Duration } / \mathrm{h} \\
\text { Trajanje/h }\end{array}$ & $\begin{array}{l}\text { Quality } \\
\text { Kvaliteta }\end{array}$ \\
\hline 1 & -50 & 2 & 25 & 2 \\
\hline 2 & -50 & 0 & 30 & 3 \\
\hline 3 & -50 & 1 & 35 & 4 \\
\hline 4 & -60 & 1 & 25 & 4 \\
\hline 5 & -60 & 2 & 30 & 3 \\
\hline 6 & -60 & 2 & 35 & 4 \\
\hline 7 & -70 & 0 & 25 & 4 \\
\hline 8 & -70 & 1 & 30 & 4 \\
\hline 9 & -70 & 2 & 35 & 2 \\
\hline
\end{tabular}

Table 2 - Experimental results

Tablica 2 - Eksperimentalni rezultati

The multiple regression model mentioned above is used to obtain the extreme points which are the optimized parameters. From the optimization theory of operational research, if $\Delta Y(X)=0$ and for any $X\left(x_{1}, x_{2}, x_{3}\right) \in R \rightarrow Y>0$, $X\left(x_{1}, x_{2}, x_{3}\right)$ must have a local extreme value. By calculation, the extreme values are freeze-drying temperature $\left(x_{1}\right)=$ -66.5 , pressure $\left(x_{2}\right)=1.23$ and duration $\left(x_{3}\right)=32.79$ and $Y$ $=4.9879$, which could be the best result.

By using these technical parameters to conduct three more experiments with the same material and vacuum freeze-drying machine, the quality of the final production was good enough. It proves that the method for optimizing the technical parameters of vacuum freeze-drying is valid. Furthermore, experiments with other materials such as porcine blue-ear disease vaccine, foot-and-mouth disease vaccine, rabies vaccine still validate the method.

\section{Conclusion}

1. In connection with the vacuum freeze-drying machine of $10 \mathrm{~m}^{2}$, the control system with computer, PLC, sensors for whole freeze-drying process is developed, including the automatic judgment of the end-point of the freeze-drying process.

2. Aiming at a kind of animal vaccine, multiple regression models for the quality with freeze-drying temperature, vacuum and duration is set up, and its confidence is above $95 \%$ by calculation.

3. According to the regression model, the freeze-drying technical parameters including freeze-drying temperature, vacuum and duration are optimized, which are freeze-drying temperature $\left(x_{1}\right)=-66.5$, pressure $\left(x_{2}\right)=1.23$ and duration $\left(x_{3}\right)=32.79$

4. The optimized technical parameters are only applied to the particular vacuum freeze-drying machine and particular animal vaccine while the optimization method advanced in this paper is applied to all the other animal vaccines produced in the same factory. 


\section{ACKNOWLEDGEMENTS}

This research work is under the support of the leaders and engineers of Nanjing Pharmaceuticals and Instruments Factory, which belongs to China Animal Husbandry Industry Co., Ltd., and also supported by "The Fundamental Research Funds for the Central Universities", NO. NS2014052.

\section{List of symbols and abbreviations Popis simbola i kratica}

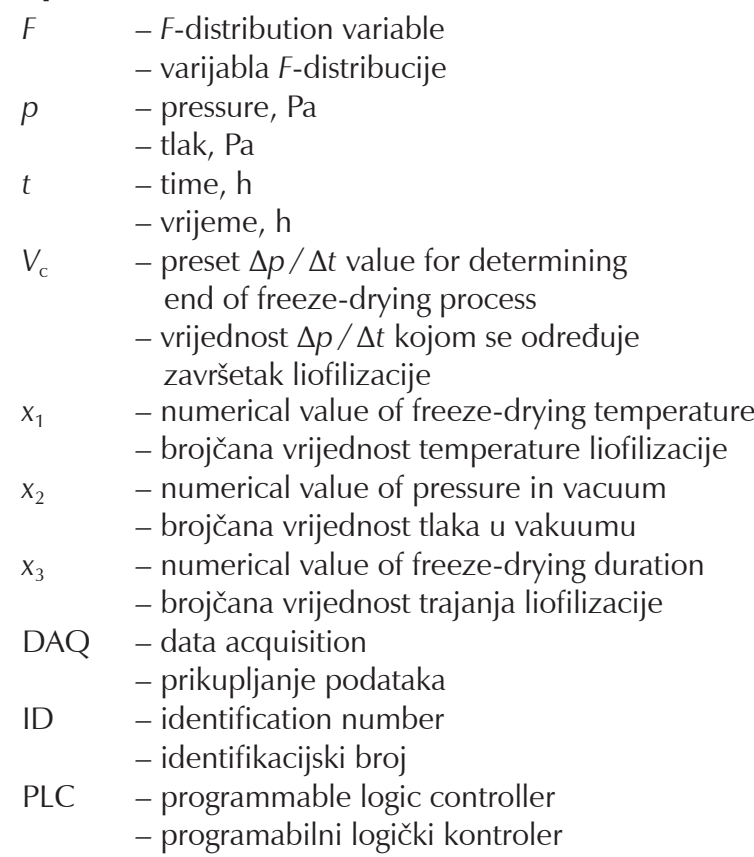

\section{References Literatura}

1. A. S. Mujumdar, Handbook of Industrial Drying, $3^{\text {rd }}$ ed., Boca Ratton, Florida, 2007.

2. A. Reyes, N. Pérez, A. Mahn, Theoretical and experimental study of freeze-drying of "loco" (Concholepas concholepas), Drying Technology 29 (2011) 1386-1395, doi: http://dx.doi. org/10.1080/07373937.2011.586479.

3. L. A. Bazyma, V. P. Guskov, A. V. Basteev, A. M. Lyashenko, V. Lyakhno, V. A. Kutovoy, The investigation of low temperature vacuum drying processes of agricultural materials, J. Food Eng. 74 (2006) 410-415, doi: http://dx.doi.org/10.1016/j.jfoodeng.2005.03.030

4. M. F. Zotarelli, B. D. A. Porciuncula, J. B. Laurindo, A convective multi-flash drying process for producing dehydrated crispy fruits, J. Food Eng. 108 (2012) 523-531, doi: http://dx.doi. org/10.1016/j.jfoodeng.2011.09.014.

5. K.-C. Yu, C.-C. Chen, P.-C. Wu, Research on application and rehydration rate of vacuum freeze drying of rice, J. Appl. Sci. 11 (2011) 135-141, doi: http://dx.doi.org/10.3923/ jas.2011.535.541.

6. M. Horgnies, Polymeric microstructures induced by freeze-drying process: comparative study of PS41-PAA271 morphologies after impregnations in water and in an alkaline solution, J. Mater. Process. Techn. 209 (2009) 5481-5486, doi: http:// dx.doi.org/10.1016/j.jmatprotec.2009.05.002.

7. A. Motevali, S. Minaei, M. H. Khoshtagaza, Evaluation of energy consumption in different drying methods, Energy Convers. Manage. 52 (2011) 1192-1199, doi: http://dx.doi. org/10.1016/j.enconman.2010.09.014.

\title{
SAŽETAK \\ Metoda za optimizaciju tehničkih parametara liofilizacije \\ X.-M. Qian, ${ }^{*}$ W.-R. Huang i P.-H. Lou
}

\begin{abstract}
Liofilizacija u vakuumu postupak je koji dehidrira materijal pri niskoj temperaturi i niskom tlaku, što ima mnogo prednosti. Kontrolni sustav dizajniran je i razvijen za određeni uređaj za liofilizaciju. Kako bi se optimizirali tehnički parametri liofilizacije, provedeno je ispitivanje od strane nadzornog sustava. Prema rezultatima, metodom kvadratnog ortogonalnog eksperimenta, analizirani su i optimizirani ključni parametri uključujući trajanje, temperaturu i razinu vakuuma liofilizacije. Ispitivanje dokazuje da optimizirani parametri vrijede za određene uređaje za liofilizaciju i određene bakterine. Dodatno, optimizirani parametri pokazuju da je liofilizacija upotrebljiva za bilo koji uređaj za liofilizaciju u vakuumu i bilo koji bakterin.
\end{abstract}

College of Mechanical and Electrical Engineering Nanjing University of Aeronautics and Astronautics 210016 Nanjing Kina
Prispjelo 31. svibnja 2013. Prihvaćeno 16. kolovoza 2013. 